\title{
Studies on the Effects of Substituting Soya Bean Meal (SBM) with Blood Meal (BM) on External Eostrus Signs and Hormonal Profile of Gilts Abonyi Festus Otaka ${ }^{1 *}$, Omeke Benjamin Chigozie $\mathrm{O}^{1}$ and Marire Benjamin $\mathrm{N}^{2}$ \\ ${ }^{1}$ Department of Animal Health and Production, University of Nigeria, Nsukka, Nigeria
}

${ }^{2}$ Department of Animal Science, Faculty of Agriculture, Enugu State University of Science and Technology, Enugu, Nigeria

\begin{abstract}
This study was conducted to evaluate the effects on external eostrus signs and hormonal profile of pigs reared with feed formulated by subtitling soya bean meal (SBM) with blood meal (BM). Blood, used to formulate the experimental diets was collected from apparently healthy cattle at slaughter, boiled and sun dried. Thereafter, the BM was used to formulate four grower pig diets: A, B, C and D, containing 50.0, 75.0, 100.0 and $0.0 \%$ (control) SBM as replacement for BM. Following feed formulation, 16 LandracexLarge White crossbred weanling pigs were selected and used for the study. They were aged 6.0 to 6.5 weeks, with average body weight of $12.24 \mathrm{~kg}$. The pigs were randomly allotted to the 4 treatment groups, each of which was further divided into two; with 2 pigs as replicate. Individual animal was maintained on experimental diet that was equivalent to $5.0 \%$ of its average body weight as ration from beginning to the end of study. At their 6.5 months of age, the gilts were observed two times daily for symptoms of eostrus. Following the manifestation of eostrus signs, scoring for the vulva changes was carried out and values obtained were compared between treatment groups at first, second and third eostrus cycles, respectively. Similarly on their forth eostrus cycle, the gilts were bled every $30 \mathrm{~min}$ for 6 hours and sera obtained was used to determine their hormonal profile. Hormone assay was done by ELISA technique. Results showed no dietary treatment affected most of the parameters investigated within the study period. Thus, age at puberty, duration of standing reflex, intensity of reddening, and swelling of the vulva and eostrus cycle length showed no significant $(P>0.05)$ variation, when compared to the control. The study showed that while the duration of standing reflex increased, intensity and duration of reddening and swelling of vulva rather decreased with eostrus cycle number. The hormonal assay showed that estradiol- $17 \beta$ levels of groups $A, B$ and $C$ were significantly $(P<0.05)$ higher than the control group $D$ animals. BM inclusion had no significant effect on Luteinizing and Follicle Stimulating Hormonal profile of the gilts, but their pulsatile release at the $3^{\text {rd }}$ and $6^{\text {th }}$ hours was evident. It is concluded that inclusion of BM in formulating pig diets under tropical humid conditions is safe. It does not interfere with some key reproductive parameters in gilts, such as their age at puberty, manifestation of eostrus signs and reproductive hormonal profile.
\end{abstract}

Keywords: Blood meal; Puberty; Eostrus; Reproductive performance; Tropical environment

\section{Introduction}

Reproductive performance in livestock is determined by four major factors, which include genetic make-up of an individual animal, management and nutrition [1]. Nutritional factors appear to be the most crucial, compared to other variables. According to Robinson [2], adequate nutrition in animals can encourage mediocre biotypes attain their full potentials, alleviate the effects of hash environmental conditions, and reduce the negative effects associated with inadequate management practices. Braun et al. [3] reported that body condition, pregnancy rates following embryo transfer, milk yield and general fertility in cows are positively correlated to improved nutrition. Studies have shown that in the female pig, under nutrition causes, delay in attainment of puberty influences the growth of antral follicles from various sizes and classes, and affects ovulation rate, foetal survival, and post weaning eostrus [4-6]. Similarly, Quesnel et al. [7] reported that eostrus signs and level of reproductive hormone in circulation of gilts are affected by level of nutrition.

Puberty, on the other hand, is indicated by the first behavoural eostrus symptoms, and usually accompanied by first ovulation. In the gilt or sow, these signs include hyperaemia, or reddening and swelling of the external genitalia, anorexia, restlessness and mounting and or being mounted by other pen mates. These signs are important so as to get them bred at the proper time and save empty days. However, there are cases where significant percentage of replacement gilts reared under temperate environments is ignorantly culled by breeders due to suspected aneostrus [8]. Similarly, according to Omeke [9], there is also high culling rate of about $13 \%$ among exotic pigs raised under tropical humid environment. Reasons advanced by the authors for this high culling rate in pigs include failure to show classical signs of eostrus, inability to detect the signs by breeders, particularly when they are weak and hormonal imbalance due to feed restriction. Feed restriction, particularly in the tropics where cost of feed is high, is an attempt by farmers to reduce production cost. Animal nutritionists have shown that the panacea for this continuous rise in prices of livestock feed ingredient, particularly those of animal origin, would be to embark on the use of agro-industrial or unconventional feed ingredients. Blood meal (BM), an abattoir waste, logically fits as a replacement for some these ingredients, by virtue of its nutritive value, availability and environmental friendliness.

However, the recommendation of FAO is that, any unconventional

*Corresponding author: Abonyi Festus Otaka, Department of Animal Health and Production, University of Nigeria, Nsukka, Nigeria, Tel: +23480-3507-8356; E-mail: festus.abonyi@unn.edu.ng

Received January 02, 2013; Accepted February 01, 2013; Published February 03, 2013

Citation: Otaka AF, Omeke Benjamin Chigozie O, Marire Benjamin N (2013) Studies on the Effects of Substituting Soya Bean Meal (SBM) with Blood Meal (BM) on External Eostrus Signs and Hormonal Profile of Gilts. J Veterinar Sci Technol 4: 133. doi:10.4172/2157-7579.1000133

Copyright: @ 2013 Otaka AF, et al. This is an open-access article distributed unde the terms of the Creative Commons Attribution License, which permits unrestricted use, distribution, and reproduction in any medium, provided the original author and source are credited. 
feed stuff should not compromise reproductive efficiency of the livestock for which it is intended (FAO) [10]. Therefore, there is need to demonstrate that inclusion of BM in pigs diet would not negatively interfere with their ovarian activities and by extension reproductive performance. This study was designed to document the effects of replacing SBM with BM on attainment of puberty, external eostrus signs, and some serum reproductive hormonal concentration of gilts reared under tropical humid conditions.

\section{Materials and Methods}

This study was conducted at the Teaching and Research Farm of the Faculty of Veterinary Medicine, University of Nigeria, Nsukka. Sixteen selected Large WhitexLandrace crossbred grower pigs, progeny of two sows and one boar were used in this study. They were quarantined for two weeks before the commencement of the study. This was done with a view of stabilizing the animals. Following this period of stabilization, the pigs were then randomly allotted to four treatment groups of 4 pigs each. Each of these groups was further divided into two, with 2 animals in each as replicate. Individual animal groups were then fed four diets: $\mathrm{A}, \mathrm{B}, \mathrm{C}$ and D formulated such that BM replaced SBM at 50.0 (Diet A), 75.0 (Diet B), 100.0 (Diet C), and 0.0\% (Diet D) (control). These represented treatments $\mathrm{T}_{1}, \mathrm{~T}_{2}, \mathrm{~T}_{3}$ and $\mathrm{T}_{4}$, respectively. Individual animal was maintained on feed equivalent to $5.0 \%$ of its average body weight [11]. The ration was divided and fed twice daily at 09.00 am and 16.00 $\mathrm{pm}$, respectively. Experimental animals were maintained on these diets, from an average age of 6.25 weeks and weight $12.24 \mathrm{~kg}$, until the end of the study period. At their average age of 5.54 months and weight range of $70.00-72.43 \mathrm{~kg}$, the gilts were then observed daily (morning and evening) for symptoms that would indicate attainment of puberty.

As none of the gilts showed these signs, two weeks later, three sexually mature boars were selected and introduced in adjacent pens, so as to have nose contact with the gilts. Following this, observations for signs of puberty attainment were continued. Within one week of introducing the boars, the signs were simultaneously manifested in each animal group, but their duration and intensity slightly differed among individual animal.

The following definitions were used:

- Pro-estrus: This was defined as the period before standing reflex, when reddening and swelling of the valve occurred.

- Standing reflex/estrus: This was the period when the gilt stood motionless, when palm pressure was applied on its back.

- Duration of external estrus symptoms: This was defined as the period before, during, and after the standing reflex, when reddening and swelling of the vulva ceased.

- Intensity: The extent of reddening and swelling of the vulva.

The intensity of vulva changes was scored from $0-3$, and the intensity recorded for individual gilt in a group was the highest degree observed during the entire period of reddening and swelling of the vulva at eostrus [8]. These observations were made through the first, second and third estrus cycles, respectively.

\section{Blood Collection}

Blood was collected with the help of other trained livestock personnel of the farm. While blood samples used for the determination of LH and oestradiol-17 $\beta$ were collected during the pro-estrus period, those used for FSH evaluation were sampled at eostrus. About $3 \mathrm{ml}$ of blood was collected from each animal by venipuncture, every thirty minutes for six hours (09.30 am-3.30 pm). Blood samples were put in identified test tubes and allowed to clot. The clots were removed and the serum then centrifuged at 2,000 rpm for three min. After this, the serum was separated from the remaining red blood cells and stored at $-20^{\circ} \mathrm{C}$, until assay the following day.

\section{Hormonal Assays}

The serum profile of Luteinizing Hormone (LH), Follicle Stimulating Hormone (FSH) and Oestradiol-17 $\beta$ of the gilts were determined using ELISA kits designed for quantitative determination of hormonal concentration in serum or plasma. The kits were FSH-08021, LH-0802-1 and ES-0702-1, respectively, (Biorex Diagnostic Limited, Northern Ireland). While serum LH and FSH values were determined every $30 \mathrm{~min}$, estradiol- $17 \beta$ was determined at $1 \mathrm{hr}$ interval. Procedures for the determination of individual hormone were carried out following manufacturer's instructions, and all assays were done in duplicate.

\section{Statistics}

Data collected were subjected to statistical analysis of variance using the PROC ANOVA statement, as found in the SAS computer software [12]. Significant differences in means were separated using Duncan method, as found in the computer package.

\section{Results}

Table 1 shows experimental animal ages at puberty, and accompanying estrus symptoms clearly shows that there was similarity in these symptoms between control groups, and those animals fed SBM replaced BM formulated diets. The pigs rather decreased with estrus number. However, pro-eostrus length at the second eostrus for animals in group $\mathrm{B}$ was significantly $(\mathrm{P}<0.05)$ higher than those in

\begin{tabular}{|c|c|c|c|c|}
\hline \multirow[b]{2}{*}{ Parameters } & \multicolumn{4}{|c|}{ Treatments } \\
\hline & $\begin{array}{c}\text { A } \\
(50.0 \% \text { BM) }\end{array}$ & $\begin{array}{c}\text { B } \\
(75.0 \% \text { BM })\end{array}$ & $\begin{array}{c}\mathrm{C} \\
(100.0 \% \mathrm{BM})\end{array}$ & $\begin{array}{c}D \\
(0.0 \% \text { BM })\end{array}$ \\
\hline $\begin{array}{l}\text { Age at puberty } \\
\text { (months) }\end{array}$ & $6.66 \pm 0.15^{\mathrm{a}}$ & $6.52 \pm 0.22^{\mathrm{a}}$ & $6.58 \pm 0.25^{a}$ & $6.53 \pm 0.10^{a}$ \\
\hline \multicolumn{5}{|c|}{ Length of pro-eostrus (days) } \\
\hline First eostrus & $2.40 \pm 0.22^{\mathrm{a}}$ & $2.25 \pm 0.19^{a}$ & $2.26 \pm 0.12^{\mathrm{a}}$ & $2.27 \pm 0.21^{\mathrm{a}}$ \\
\hline Second eostrus & $1.70 \pm 0.05^{\mathrm{ab}}$ & $1.76 \pm 0.10^{\mathrm{a}}$ & $1.44 \pm 0.10^{\mathrm{b}}$ & $1.66 \pm 0.08^{\mathrm{ab}}$ \\
\hline Third eostrus & $1.29 \pm 0.10^{\mathrm{a}}$ & $1.32 \pm 0.16^{a}$ & $1.29 \pm 0.10^{\mathrm{a}}$ & $1.32 \pm 0.15^{\mathrm{a}}$ \\
\hline \multicolumn{5}{|c|}{ Standing reflex dur } \\
\hline First eostrus & $1.00 \pm 0.08^{\mathrm{a}}$ & 1. $48 \pm 0.17^{\mathrm{a}}$ & $1.34 \pm 0.05^{\mathrm{a}}$ & 1. $34 \pm 0.20^{\mathrm{a}}$ \\
\hline Second eostrus & $1.95 \pm 0.03^{a}$ & $1.97 \pm 0.16^{\mathrm{a}}$ & $2.17 \pm 0.17^{\mathrm{a}}$ & $1.87 \pm 0.20^{a}$ \\
\hline Third eostrus & $1.98 \pm 0.02^{a}$ & $2.06 \pm 0.13^{a}$ & $1.97 \pm 0.15^{\mathrm{a}}$ & $1.96 \pm 0.16$ \\
\hline \multicolumn{5}{|c|}{ Intensity of reddening and swelling of vulva (RSV) } \\
\hline First eostrus & $2.87 \pm 0.04^{\mathrm{a}}$ & $2.86 \pm 0.06^{a}$ & 2. $82 \pm 0.07^{a}$ & $2.80 \pm 0.09^{a}$ \\
\hline Second eostrus & $2.57 \pm 0.09^{a}$ & 2. $64 \pm 0.07^{\mathrm{a}}$ & $2.53 \pm 0.20^{\mathrm{a}}$ & $2.50 \pm 0.02^{a}$ \\
\hline Third eostrus & $2.02 \pm 0.02^{a}$ & $2.07 \pm 0.03^{a}$ & $2.00 \pm 0.03^{a}$ & $2.01 \pm 0.17$ \\
\hline \multicolumn{5}{|c|}{ Duration of RSV (days) } \\
\hline First eostrus & $7.76 \pm 0.19^{a}$ & $7.78 \pm 0.24^{\mathrm{a}}$ & $7.60 \pm 0.23^{\mathrm{a}}$ & $7.80 \pm 0.09^{\mathrm{a}}$ \\
\hline Second eostrus & $7.70 \pm 0.21^{a}$ & $8.02 \pm 0.32^{a}$ & $7.53 \pm 0.31^{\mathrm{a}}$ & $7.50 \pm 0.34^{a}$ \\
\hline Thirds eostrus & $7.36 \pm 0.20^{a}$ & $7.44 \pm 0.19^{a}$ & $7.47 \pm 0.35^{\mathrm{a}}$ & $7.31 \pm 0.31^{\mathrm{a}}$ \\
\hline \multicolumn{5}{|l|}{ Duration of eostru } \\
\hline First eostrus & $20.08 \pm 0.97^{a}$ & $19.80 \pm 0.80^{\mathrm{a}}$ & $20.88 \pm 0.54^{\mathrm{a}}$ & $21.05 \pm 1.02$ \\
\hline Second eostr & $20.50 \pm 0.96^{\mathrm{a}}$ & $21.80 \pm 0.97^{\mathrm{a}}$ & $21.42 \pm 0.64^{\mathrm{a}}$ & $20.17 \pm 0.54$ \\
\hline Third eostrus & $18.92 \pm 0.58^{\mathrm{a}}$ & $18.60 \pm 0.68^{\mathrm{a}}$ & $19.23 \pm 0.63^{\mathrm{a}}$ & $19.40 \pm 0.68$ \\
\hline
\end{tabular}

Values on the same row with different superscripts are significantly $(P<0.05)$ different

Table 1: Age at puberty external signs at first, second and third estrus cycles of gilts fed SBM replaced BM formulated diets. 


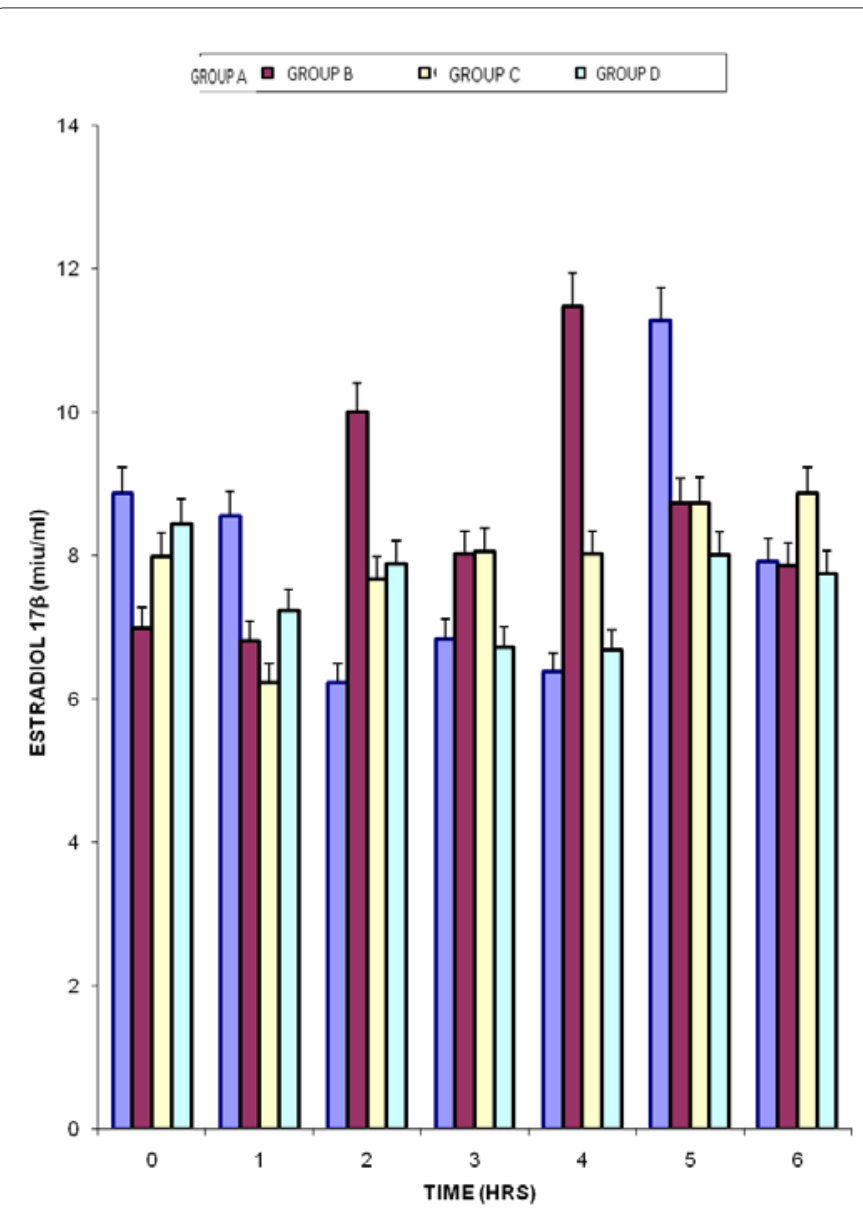

Figure 1: Serum Estradiol- 17P Profile of Pigs Fed with SBM Replaced BM Formulated Diets.

group C which were fed with $100 \%$ SBM replaced diet. On the other hand, eostrus length range of $19.80 \pm 0.80$ to $21.05 \pm 1.02$ days slightly increased by the second estrus, but had again reduced to between 18.60 \pm 0.68 to $19.40 \pm 0.68$ days by the third eostrus cycle.

The effect of substituting SBM with BM in formulating pig diets on serum eostradiol- $17 \beta$ concentration of gilts is presented in figure 1 . The mean values of eostradiol- $17 \beta$ obtained ranged from $6.24 \pm 0.38$ to $11.48 \pm 0.57 \mathrm{Pg} / \mathrm{ml}$. High mean values of $11.28 \pm 0.78,11.48 \pm 0.57$, and $9.87 \pm 0.79 \mathrm{Pg} / \mathrm{ml}$ for gilts in treatment groups $\mathrm{A}, \mathrm{B}$ and $\mathrm{C}$ were significantly $(\mathrm{P}<0.05)$ higher than highest mean value of $8.01 \pm 0.93 \mathrm{Pg} /$ $\mathrm{ml}$, recorded for the control group $\mathrm{D}$ gilts.

The result showed that dietary treatment did not significantly affect the LH profile of the experimental animals within the study period. Within each treatment group, it was observed that there was an evidence of LH pulsatile release at the third and sixth hours of sampling. By the third hour, a peak valued was reached in each of the groups. Thus at this period, the mean $\mathrm{LH}$ values of $14.40 \pm 0.25,14.40 \pm 0.25,14.93 \pm$ $1.89,13.45 \pm 0.75$ and $15.58 \pm 1.56 \mathrm{miu} / \mathrm{ml}$ were recorded for animals in groups A, B, C and D, respectively (Figure 2 ).

Serum FSH concentrations ( $\mathrm{miu} / \mathrm{ml}$ ) of gilts fed with SBM replaced $\mathrm{BM}$ formulated diets (A, B, C and D) are presented in figure 3 .

The results showed that inclusion of BM in the diets of the three animal groups $\left(\mathrm{T}_{1}, \mathrm{~T}_{2}\right.$ and $\left.\mathrm{T}_{3}\right)$ did not alter their mean serum FSH value, relative to the control. Within each treatment group, the values obtained followed similar trend as mean LH values. Similarly, there was also evidence of FSH surge at the third and sixth hours, respectively. However, highest mean concentration levels recorded by this period were lower than the values obtained for $\mathrm{LH}$, but the surge was sustained for a longer period.

\section{Discussion}

Use of BM in evaluating reproductive performance in the pig has not been fairly documented. Results showed that there was no significance $(\mathrm{P}>0.05)$ difference in the mean age at attainment of puberty among all the four groups. Similarly, none of the gilts used in this trial showed delayed puberty ( $>8$ months). Age range of $6.52 \pm 0.22$ to $6.86 \pm 0.15$ months noted in this study is shorter than 212 days $(7.07$ months), reported among pure breed pigs [8]. This however, appears to be conventional for crossbred pigs, and is in agreement with the findings of Agbagha et al. [13], that crossbred pigs attain puberty earlier than their pure bred counterparts. Similarly, the introduction of the sexually mature boars and subsequent manifestation of eostrus signs by the gilts in their individual pens, as was noted in this study, could be an indication that the stimulating action of pheromones secreted by the boars was strong enough to induce puberty. It is known that social factors such as transportation, mixing of gilts from different sources and boar contact, influence attainment of puberty in pigs.

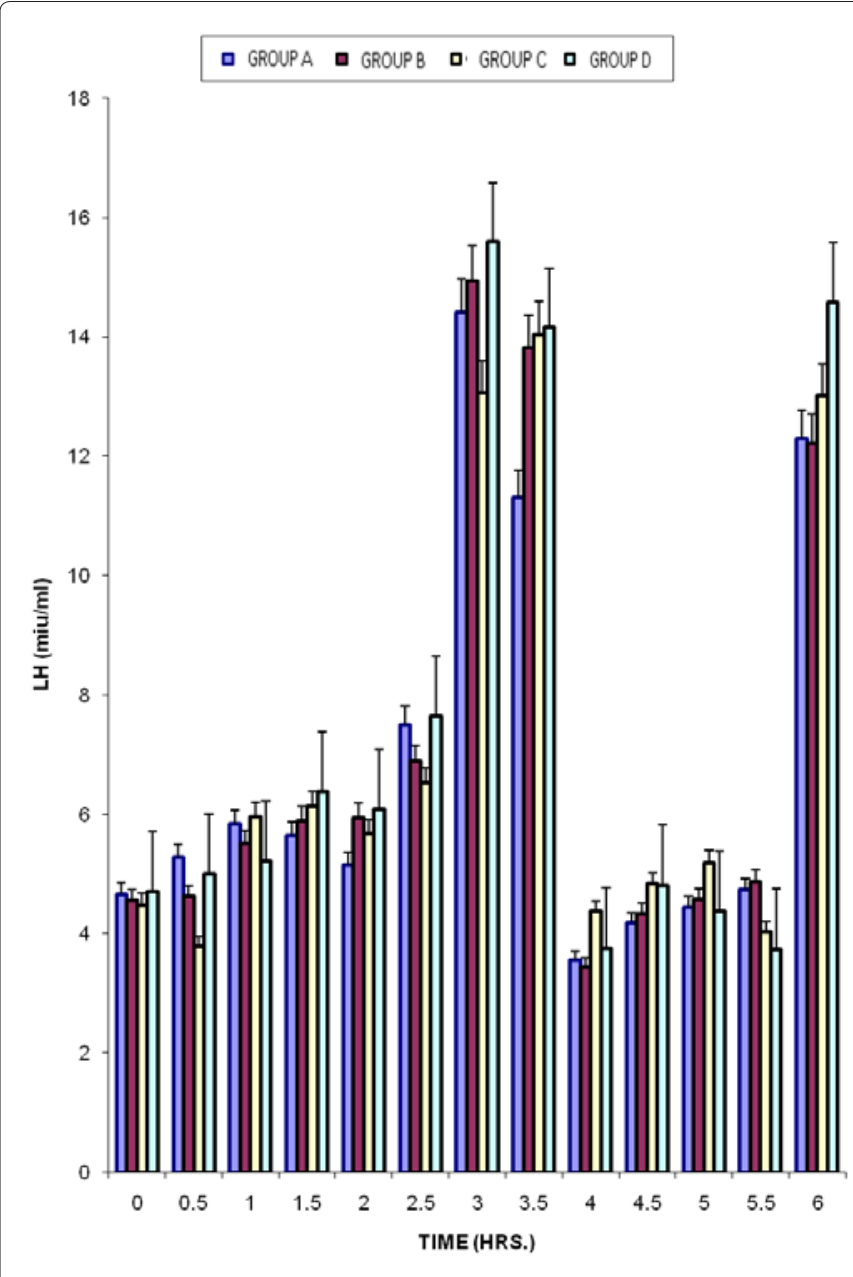

Figure 2: Lh Profile of Gilts Fed BM Protein Diets. 


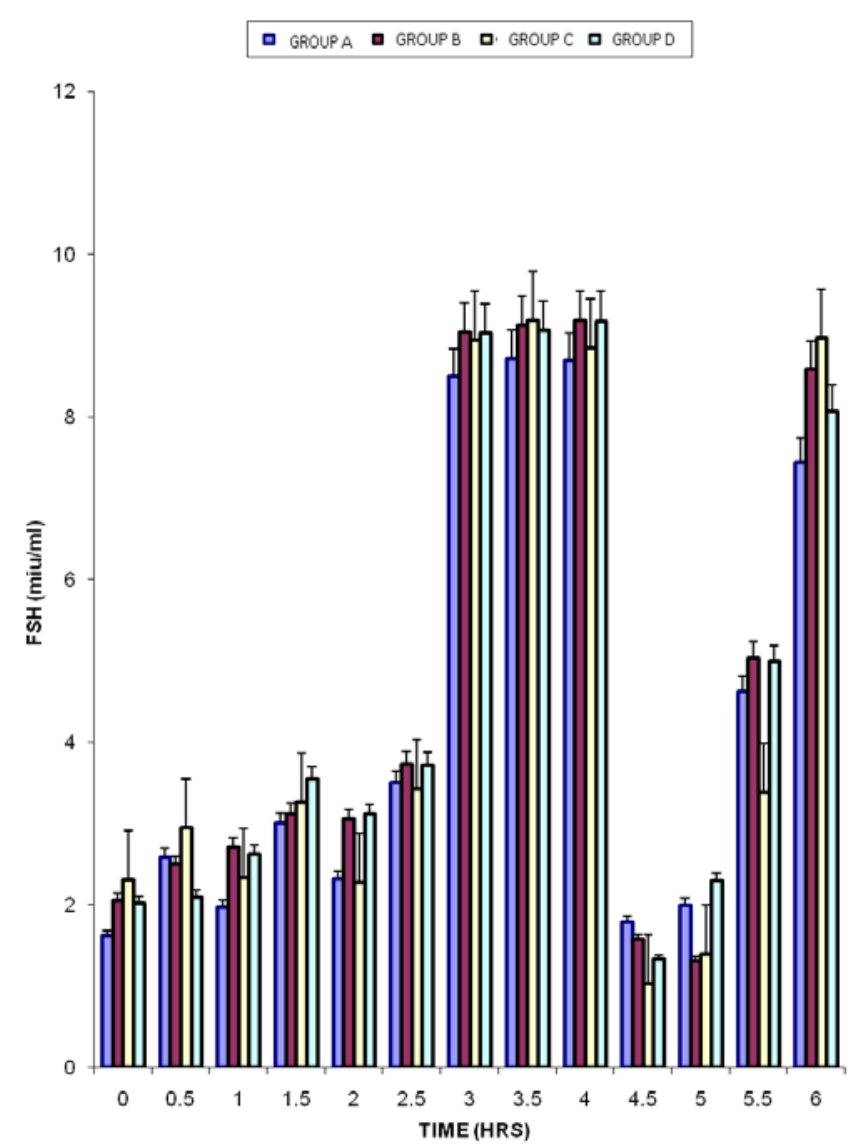

Figure 3: Serum Fsh Concentration Of Gilts Fed With SBM Replaced BM Formulated Diets.

Studies on external eostrus signs showed that BM inclusion in grower pig diets did not influence most of the parameters investigated within the study period. Duration of standing reflex, intensity of reddening and swelling of the vulva and estrus cycle length showed no significant variation, when compared to the control. This observation lays credence to the observations of other authors [14,15], that genetic differences and level of reproductive hormones in circulation play vital roles in the manifestations of estrus symptoms in the pig. However, it was noted that pigs fed diet B (SBM replacement with $75.0 \% \mathrm{MB}$ ) had a slightly longer pro-eostrus length at the second eostrus cycle, than other three groups. Similarly, durations of pro eostrus period in the first and second estrus cycles were observed to have lasted longer, compared to the third cycle in all the groups. These findings are in contrary to the report [16], that length of pro-estrus increases with estrus number. Differences in the two findings may be attributed to management, environmental and nutritional differences, which Quesnel et al. [7] noted could affect pro-eostrus duration in pigs.

It was observed that duration of reddening and swelling decreased with eostrus number, this is line with the reports of Anne-Marie [8], that intensity of reddening and swelling decrease as the number of eostrus cycles increase in gilts. Mean estrus cycle length was slightly reduced by the third estrus, but ranged from $18.60 \pm 0.18$ to $21.80+$ 0.97 days. These range values were slightly shorter than range of 19.15 to 22.00 days, reported by Anne-Marie [8], for multiparous sows reared under temperate conditions. Thus, differences in the results obtained might be attributed to variation in age or parity number of animals used, which Ozasa and Gould [17] noted could affect estrus cycle length due to changes with age on the receptor mechanism in the vulva tissues. Secondly, differences could also be attributed to differences in photoperiods, Walker and Young [14] reported that variation in photoperiods affects duration of eostrus cycle in the pig. In those studies, animals were exposed to extreme photoperiods than the normal changes in day length, in the present study. The present observation is, however, within normal 21 days reported for pigs in Swine Production (calvetupenn.edu/projects/swine/bio/fem/estr/hm.ml).

All the hormones assayed were detectable in sera and displayed pulsatile pattern during the assay period. This was an indication that all gilts used were cycling during the period they were bled. According to Lutz et al. [18], onset of puberty is associated with elevated levels of plasma or serum estrogen and exhibition of external eostrus symptoms, which is in close agreement to the findings of the present investigation. The result of this study showed that while the gilts fed with BM included diets that had higher serum eostradiol-17 $\beta$ concentration, than the control fed 100.0\% SBM diet; the latter also had higher LH values than them. These differences in hormonal values may be attributed to the effects of nutrition on the pigs' performance [7]. However, the observed variations between these two groups not withstanding any significant $(\mathrm{P}>0.05)$ differences in the degree of manifestation of the external eostrus symptoms were noted among all the four treatment groups. The non variation of these signs could be due to the fact that manifestations of eostrus symptoms in pigs are highly controlled by the action of the LH and estradiol-17 $\beta$ in circulation [14]. Significant rise in these reproductive hormones may also be indicators of follicular growth and subsequent ovulation that could prompt pregnancy in mated female pigs.

It was noted that two animals, one each from groups $\mathrm{C}$ and $\mathrm{D}$ that showed very weak eostrus symptoms, had serum LH, eostral-17 $\beta$ and FSH values that were comparable to others, which showed obvious signs. It is important to note that non-exhibition of these symptoms may be a reason by pig breeders, particularly those within the study area, to cull their gilt or sow on bases of non performance [18]. It will, therefore, be necessary to determine the hormonal profile, especially serum or plasma concentrations of LH, eostradiol-17 $\beta$, and FSH of breeder sow/replacement gilts, before taking final decision on whether they should be culled or not, particularly on reasons of anoestrus.

This research has highlighted the relevance of replacing SBM with $\mathrm{BM}$, in formulating grower pig diets. In conclusion, the observation of this study is that availing BM diets to female grower pigs under tropical humid conditions do not negatively interfere with some reproductive parameters, particularly their age at puberty and reproductive hormonal profile.

\section{Acknowledgments}

Authors are grateful to STEP-B/World Bank Project, University of Nigeria Nsukka, for supplying some of the equipment we used. We acknowledge the management and staff of Glanson Diagnostic Laboratory Awka, Anambra state Nigeria, for permission to use facilities in their laboratory, for the determination of the hormones. Professors S.V.O. Shoyinka and A.O. Anaga of the Faculty of Veterinary Medicine, University of Nigeria Nsukka, are appreciated for their constructive criticism of this project.

\section{References}

1. Nnadi PA, Kamalu TN, Onah DN (2007) Effect of dietary protein supplementation on performance of West African dwarf (WAD) does during pregnancy and lactation. Small Rumin Res 71: 200-204

2. Robinson JJ (1990) Nutrition in the reproduction of farm animals. Nutrition Research Review 3: 253-276. 
Citation: Otaka AF, Omeke Benjamin Chigozie O, Marire Benjamin N (2013) Studies on the Effects of Substituting Soya Bean Meal (SBM) with Blood Meal (BM) on External Eostrus Signs and Hormonal Profile of Gilts. J Veterinar Sci Technol 4: 133. doi:10.4172/2157-7579.1000133

3. Braun RK, Donovan GA, Tran TO (1986) Importance of body condition scoring in dairy cattle. In: Proceedings of the Annual Meeting of the American Association of Bovine Practitioners.

4. Robertson DM, Foulds LM, Fry RC, Cummins JT, Clarke I (1991) Circulating half-lives of follicle-stimulating hormones and luteinizing hormone in pituitary extracts and isoform fractions of overiectomised and intact ewes. Endocrinology 129: $1805-1813$

5. Oyedipe EO, Buvanendran V, Eduvie LO (1982) Some factors affecting the reproductive performance of White Fulani (Bunaji) cattle. Tropical Agriculture 59: $231-234$

6. Prunier A, Quesnel H (2000) Influence of the nutritional status on ovarian development in female pigs. Anim Reprod Sci 60: 185-197.

7. Quesnel H, Pasquier A, Mounier AM, Prunier A (2000) Feed restriction in cyclic gilts: gonadotrophin-independent effects on follicular growth. Reprod Nutr Dev 40: 405-414.

8. Anne-Marie (1987) Puberty and eostrus in gilts: Clinical morphological and endocrinological studies. University of Agricultural Sciences, Sweden.

9. Omeke BCO (1990) Seasonal breeding performance in the field of Landrace and Large White pigs under humid environment. World Review of Animal Production 25: 33-36

10. FAO (1978) Processing and Utilization of animal products. Food and Agriculture Organization, Agricultural Development, Paper No. 68.
11. Onyimonyi (2002) Nutritional evaluation of cassava peel and bambara waste in pig diet. University of Nigeria, Nsukka.

12. SAS Institute (1999) SASSAT users' guide version 8 for window. ASA Institute Inc. Cary, NC, USA.

13. Agbagha FM, Ezema FU, Omeke BCO (2001) Studies of management effects on fertility of purebred and crossbred exotic gilts in two breeding farms at Nsukka, Nigeria. Nigerian Journal of Animal Production 28: 20-25.

14. Walker B, Young BA (1992) Modelling the development of uterine components and sow body composition in response to nutrient intake during pregnancy. Livest Prod Sci 30: 251-264.

15. Sterning M (1995) Oestrous symptoms in primiparous sows. 2. Factors influencing the duration and intensity of external oestrus symptoms. Anim Reprod Sci 40: 165-174.

16. Anderson AM, Einarson S, Edqvist LE, Lundchein M (1984) Endocrine pattern and external oestrus symptoms at second and fourth oestrus in gilts. Anim Reprod Sci 6: 301-310.

17. Ozasa H, Gould KG (1982) Demonstration and characterization of estrogen receptor in chimpanzee sex skin: correlation between nuclear receptor level and degree of swelling. Endocrinology 111: 125-131.

18. Lutz JB, Rampacek GB, Kraeling RR, Pinkert CA (1984) Serum luteinizing hormone and estrogen profiles before puberty in the gilt. J Anim Sci 58: 686691. 